\title{
The Covid-19 Learning Crisis as a Challenge and an Opportunity for Schools: An Evidence Review and Conceptual Synthesis of Research-Based Tools for Sustainable Change
}

\author{
Ritikka Hofmann ${ }^{\star 1}$, Gabrielle Arenge², Siobhan Dickens ${ }^{2}$, Javiera \\ Marfan $^{2}$, Mairead Ryan ${ }^{3}$, Ngee Derk Tiong ${ }^{2}$, Bhaveet Radia ${ }^{4}$ And \\ LENKA JANIK BLASKOVA ${ }^{2}$
}

$\approx$ This paper advances our understanding of how schools can become change agents capable of transforming local practice to address the challenges arising from the Covid-19 pandemic. It presents a novel application of cultural-historical activity theory to reinterpret evidence on widespread learning loss and increasing educational inequities resulting from the pandemic, and to identify scalable transformative learning opportunities through reframing the crisis as a double stimulation. By reviewing evidence of the emerging educational landscape, we first develop a picture of the new 'problem space' upon which schools must act. We develop a problem space map to serve as the first stimulus to articulate local challenges. Integrating this problem space with research on professional change, we identify conceptual tools to capture learning gaps and implement pedagogic interventions at scale, in order to enhance schools' agency in directly addressing the crisis. These tools can act as the second stimulus, enabling educators to address local challenges. We conclude by discussing the Covid-19 educational crisis as a unique stimulus for professional learning and outline the potential for durable shifts in educational thinking and practice beyond the pandemic. We argue that this unprecedented historic disruption can be harnessed as a transformative professional learning opportunity. In particular, we consider how research on professional change offers local, scalable interventions and tools that can support educators in preventing the new insights from 'slipping away' post-pandemic. Utilising the notions of boundaries and tool-mediated professional change, we examine the ways in which

$1{ }^{\star}$ Corresponding Author. Faculty of Education, University of Cambridge, United Kingdom; rjph2@cam.ac.uk.

2 Faculty of Education, University of Cambridge, United Kingdom.

3 MRC Epidemiology Unit, University of Cambridge, United Kingdom.

4 University of Cambridge, United Kingdom \& Guys \& St. Thomas NHS Foundation Trust. 
this disruption generates opportunities to envision alternative futures for equitable learning in school.

Keywords: Covid-19, learning loss, cultural-historical activity theory, implementation, transformative agency 


\title{
Kriza učenja v obdobju covida-19 kot izziv in priložnost za šole: pregled dokazov in konceptualna sinteza na raziskavah temelječih orodij za trajnostne spremembe
}

\author{
Ritikka Hofmann, Gabrielle Arenge, Siobhan Dickens, Javiera \\ Marfan, Mairead Ryan, Ngee Derk Tiong, Bhaveet Radia in \\ LENKA JANIK BLASKOVA
}

$\propto$ Prispevek poglablja naše razumevanje, kako lahko šole postanejo nosilke sprememb, ki lahko preoblikujejo lokalno prakso, da bi se tako spoprijele z izzivi, ki izhajajo iz pandemije covida-19. Predstavlja izvirno uporabo kulturnozgodovinske aktivnostne teorije, $s$ katero želi reinterpretirati dokaze o razširjeni izgubi učenja in vse večji neenakosti v izobraževanju, ki sta posledica pandemije, ter prepoznati inovativne priložnosti za transformativno učenje s preoblikovanjem krize kot dvojne spodbude. S pregledom dokazov o nastajajočem izobraževalnem okolju najprej oblikujemo sliko novega "problemskega prostora «, po katerem morajo šole delovati. Razvijamo zemljevid problemskega prostora, ki je prva spodbuda za izražanje lokalnih izzivov. S povezovanjem tega problemskega prostora $\mathrm{z}$ raziskavami o profesionalnih spremembah opredelimo konceptualna orodja, da bi zajeli učne vrzeli in izvedli pedagoške ukrepe v velikem obsegu ter tako okrepili delovanje šol pri neposrednem reševanju krize. Ta orodja lahko delujejo kot druga spodbuda, ki učiteljem omogoča, da se lotijo lokalnih izzivov. Na koncu razpravljamo o izobraževalni krizi v obdobju covida-19 kot edinstveni spodbudi za profesionalno učenje ter predstavljamo možnosti za trajne premike v izobraževalnem razmišljanju in praksi po pandemiji. Trdimo, da lahko to zgodovinsko motnjo brez primere izkoristimo kot priložnost za transformativno strokovno učenje. Zlasti razmišljamo o tem, kako raziskave o profesionalnih spremembah ponujajo lokalne, razširjene intervencije in orodja, ki lahko pomagajo učiteljem preprečiti, da bi nova spoznanja po pandemiji ostala prezrta. Z uporabo pojmov meja in $\mathrm{z}$ orodjem posredovane profesionalne spremembe preučujemo načine, kako ta motnja ustvarja priložnosti za predvidevanje alternativnih prihodnosti za pravično učenje $\mathrm{v}$ šoli.

Ključne besede: covid-19, izguba učenja, kulturnozgodovinska aktivnostna teorija, implementacija, transformativno delovanje 


\section{Introduction}

In spring 2020, teachers faced the unprecedented task of educating 1.4 billion students remotely worldwide due to Covid-19 (UNESCO, 2021). In the United Kingdom alone, $98 \%$ of primary and secondary students began learning from home, including many of the most vulnerable students (Department for Education (DfE), 2020a). Even short gaps in schooling can lead to lost learning (Patrinos \& Donnelly, 2021), thus concern about the pandemic's adverse effects on children quickly arose. Entering 2021, over 250 million children were still affected by ongoing school closures, and many more by educational disruptions (UNESCO, 2021). The present paper addresses schools' transformative agency in responding to this educational crisis.

The widespread educational disruption has led to growing acknowledgement that returning to what was before is neither viable nor desirable for many schools post-pandemic. Teachers and schools face significant challenges, involving cumulative learning loss for most children (Azevedo et al., 2020) and problems in students' confidence and physical and mental wellbeing (DfE, 202ob), which exacerbate existing local and global educational inequalities (UNESCO et al., 2020). These challenges take place alongside teachers' elevated stress and reduced wellbeing (Aperribai et al., 2020). Reduced resources for schooling due to economic circumstances also impact teachers' capacity to address changing needs (Julius et al., 2020). It will not be feasible for most countries to address the widespread adverse effects at the individual level; a great deal of expectation will fall on schools and teachers. Rapid change within schools is needed to ensure that the pandemic's negative effects on teaching and learning are mitigated effectively. International agencies have proposed the need for policies defining a vision for education as a roadmap to improve longterm outcomes and equality (UNESCO, 2020). Although policy mandates can influence the definition and scope of this vision by setting goals, achievement expectations and their related inducements (Datnow \& Park, 2009; Honig, 2006), how this vision translates into actual practice will be a highly local process (Ball et al. 2012; Niemi, 2021).

The pandemic has played out in varied ways within and between countries. While Covid-19 has exacerbated pre-existing inequalities, it has also revealed latent educational resources (OECD, 2021): whereas some high-income countries (HICs) struggled to implement remote teaching despite reasonable resources (Cullinane \& Montacute, 2020; Eickelmann \& Drossel, 2020), in some low-income countries (LICs) regional responses to Covid-19 were facilitated by pre-existing efforts to address educational inequalities (ASER, 2020; 
Sabates, 2020). Similarly, there is significant variation within countries as to how schools have experienced and addressed the pandemic (e.g., Andrew et al., 2020; Ermenc \& Urbančič, 2021; Huber et al., 2020; Yorke et al., 2020). Consequently, locally responsive solutions are required in addressing the pandemic's educational impact. We may hereby look to new places for learning.

The significant demands notwithstanding, evidence of teacher agency in responding to the pandemic demonstrates capacity within the system to adapt to changing circumstances (Ermenc \& Urbančič, 2021; Gudmundsdottir \& Hathaway, 2020; Niemi \& Kousa, 2020; Ofsted, 2021). However, no system can sustain emergency circumstances indefinitely. Policies and resources are needed to continue supporting schools' efforts beyond the pandemic to capture and foster professional learning. We therefore ask: what evidence-informed approaches exist that can facilitate transformative agency in schools, helping sustain new insights and identify and address learning loss in a locally responsive manner at such scale beyond the pandemic?

In order to support such adaptations at scale, we need to understand the mechanisms by which teacher learning occurs (Opfer \& Pedder, 2011). Research syntheses show that effective contextually adaptive professional learning opportunities enable teachers to gain new insights into their own practice (Kennedy, 2019). Beyond existing practice, to respond to Covid-19 and its aftermath, teachers literally need to learn what is not yet there (Engeström, 2001). The literature suggests this requires new professional learning opportunities, including time to collaborate in order to develop and share new pedagogic practice within and across schools (Darling-Hammond \& Hyler, 2020). However, mere reflection on practice is not sufficient for transformative agency: to enable teachers to learn what is not yet there, they need tools that can enable them to see, and collaboratively work on, the emerging problem space in new ways (Rainio \& Hofmann, 2015, 2021; Soini et al., 2016).

Working with the understanding of change as a tool-mediated process, we draw on cultural-historical activity theory (CHAT) and Vygotsky's notion of double stimulation as a conceptual mechanism of transformative agency (Sannino, 2015). In Section 2, we use emerging evidence from schooling in the pandemic to map the problem space facing teachers, anchoring evidence in our own UK context, and highlighting how the phenomenon differs in other settings. We discuss how this map can serve as a first stimulus for researchers and educators to identify and articulate their local problems, competing priorities and new possibilities. In Section 3, we introduce research-based conceptual tools that can act as a second stimulus for teachers to collaboratively capture, design and effect change at the school level. Finally, we theoretically reframe 
the Covid-19 crisis as a unique stimulus for professional learning and outline the potential for durable shifts in educational thinking and practice beyond the pandemic. This paper advances our understanding of how schools can become change agents capable of reimagining local practice in order to address the challenges arising from the Covid-19 pandemic.

\section{Reviewing the evidence: Mapping the problem space for pandemic and post-pandemic education}

\section{Theoretical and methodological framing}

In CHAT, the 'object' of collective activities is often described as the problem space that orients the activity's efforts. In school teaching and learning, teachers work on the problem space of student learning with the help of mediational tools - curricula, pedagogic approaches, teaching materials, assessments - to achieve desired outcomes (Engeström \& Sannino, 2010). Problem space does not signal this object - students' learning - as being problematic, but rather indicates that it is the activity's motivator. In this section, we explore the changing problem space facing schools by reviewing emerging evidence from the UK and beyond. We extend the evidence base of the pandemic's impact on schools by synthesising the possible dimensions in which schools in different locations may face challenges and utilise resources.

Informed by Vygotsky's notion of the double stimulation as the mechanism by which transformative agency becomes possible (Sannino, 2015), we offer our mapping exercise as the first stimulus, the initial problem situation that needs addressing. While the problems of one's professional practice influence practitioners' work, their nature is not always evident to participants, especially in the unprecedented pandemic circumstance. Synthesising and mapping key dimensions of possible impact can help educators and researchers to capture and articulate the local problem space for their practice. In order to draw a holistic picture of the challenges facing individual schools and educators, our mapping exercise examines data about learning loss, children's health, teacher agency, wellbeing and school leadership. Drawing on UK and global evidence, we illustrate geographical and institutional variation in the challenges.

The evidence base is rapidly evolving. We have monitored and included evidence published between March 2020 and June 2021 using a range of sources to identify emerging data from academic databases (ERIC, Scopus, WoS, BEI, Google Scholar), pre-prints, and reports from international and UK-based organisations. As well as reviewing key UK data, we have assessed evidence from 
various European and global locations, accessing documents in multiple languages. The evidence has been prioritised using the following criteria: (1) most recent; (2) high quality; (3) offers comparison with the UK; (4) cumulative since the beginning of the pandemic.

Capturing actual impacts on learning may take years, but there are ongoing efforts to capture emergent learning losses using both objective and proxy measures (Ofsted 2020a, b, c; Sharp et al., 2020; UNESCO et al., 2020). Early findings from Australia, Europe, the UK and the US show that although not all children have experienced learning losses, many children have lost between one and five months of learning (Education Endowment Foundation (EEF), 2020; Patrinos \& Donnelly, 2021), while simulations project up to one year or more of learning loss in some LICs (Angrist et al., 2021). Differences have emerged across subject areas and age groups, while socioeconomically disadvantaged and racially marginalised learners have often experienced greater losses (EEF, 2020; Patrinos \& Donnelly, 2021). Measuring actual learning losses systematically is proving challenging due to a lack of assessment standardisation (Middleton, 2020), a lack of system-wide approaches (UNESCO et al., 2020) and inaccurate/incomplete results due to missing assessment data, low response rates and sampling biases (Crenna-Jennings et al., 2021; Wyse et al, 2020). Many schools are using local measures to identify and address learning losses, but there are large differences in the extent to which teachers are tracking student learning in line with existing inequalities (Hofmann et al., 2020; Ofsted, 2020b; UNESCO et al., 2020), while a lack of appropriate and comprehensive local assessment instruments poses further barriers (Ofsted, 202ob). Current assessment instruments commonly focus on core subjects such as literacy and numeracy (Ofsted, 202ob), but real-time evidence suggests learning losses may be far wider (Ofsted, 2020a, b). With an emergent and incomplete picture of Covid-19's educational impact (Harris \& Jones, 2020), schools must engage in rapid real-time decision making with very imperfect data. This sketch of the nature of the evidence base illuminates the challenge for schools and provides a context for interpreting our findings.

\section{Learning loss}

Four main mechanisms appear to be shaping learning loss: how much time children spend on learning; what curriculum content they cover; how they are learning, and individual and systemic readiness for remote and disrupted learning (OECD, n.d.; Vuorikari et al., 2020). Children have spent substantial but varied amounts of time out of school due to closures, absences and 
drop-outs (Sibieta \& Robinson, 2020; UNESCO et al., 2020) and typically spend less time on educational activities in remote learning than in schooling-as-usual (Andrew et al., 2020; Gustafsson \& Nuga, 2020). Moreover, learning time is unequally distributed in line with existing inequalities (Alban Conto et al., 2020; Bayrakdar \& Guveli, 2020; Eivers et al., 2020; Green, 2020). UK children from poorer households are estimated to have spent 7-15 fewer days learning between March and September 2020 than their better-off peers (Andrew et al., 2020). In Ethiopia (over nine-months of school closures), teachers often provided welfare support rather than educational activities, while urban students received more teacher support than rural students (Yorke et al., 2020). Ethnicity-related disparities in the extent and nature of access to remote learning are also reported, such as amongst Roma learners (Bešter \& Pirc, 2020). Finally, reduced curriculum coverage has been reported at institutional and system levels, especially early in the pandemic (Alam \& Tiwari, 2020; Ofqual, 2020; Ofsted, 2021), but the nature, extent and impact of this is not yet known.

Remote and digital learning have been used to mitigate learning loss, yet limitations in infrastructure, home-based support (Sabates et al., 2021), and intended and actualised provision limit learning and exacerbate inequities even in HICs. Whereas $75 \%$ or more of children in Italy, Norway, Portugal and Romania reported having daily online interactions with their teachers during the spring 2020 lockdown, this was true of only 50-75\% in France, Ireland, Spain and Switzerland, and $34-41 \%$ in Germany, Austria and Slovenia (Vuorikari et al., 2020). In the UK, over half of private-school students took part in daily digital lessons in Lockdown 1, compared to only $30 \%$ of middle-class and $16 \%$ of working-class students from state-funded schools (Cullinane \& Montacute, 2020). Although UK provision of digital live lessons has increased dramatically since the first lockdown, disparities between richer and poorer households' access have increased (Montacute \& Cullinane, 2021). A similar divide exists globally. Ninety-five percent of HICs use online platforms as the main source of remote learning, compared to only $63 \%$ of LICs, with greater use of radio and television (UNESCO et al., 2020). The often necessary shift from two-way, dialogic classrooms to asynchronous, monologic modes of (remote) delivery such as workbooks, video, television/radio and SMS (Andrew et al., 2020; Montacute \& Cullinane, 2021) has created concomitant challenges to maintaining high-quality communication, assessment and feedback (Alam \& Tiwari, 2020; Lucas et al., 2020; Ofsted, 2021). The picture is more complex in fully or partially open schools; inquiry-based, collaborative and hands-on pedagogic strategies are reported as casualties of public health restrictions in the UK (Ofsted, 2020c; Sharp et al., 2020). In LICs, however, smaller class sizes associated with 
partial openings provide more opportunities for classroom dialogue and targeted support (McAleavy, 2020). This illustrates the context-specific nature of actualised learning loss and the mechanisms contributing to it.

\section{Children's wellbeing and learning conditions}

Despite evidence that health and wellbeing are independently associated with educational attainment (e.g., Faught et al., 2019), discussions in the UK have largely framed these as peripheral educational concerns in the pandemic. UK reports highlight disparities in the impact of the pandemic on health and wellbeing across subgroups of the school population (e.g., ImpactEd). Insufficient study space, equipment and social support in the home has decreased the productivity of remote learning in less well-resourced families and ethnic minorities, as well as for children with special education needs (Andrew et al., 2020; Radhakrishnan et al., 2021; Scottish Government, 2020). Children from lower socioeconomic status (SES) groups are most reliant on their school for regular meals, physical activity opportunities and social support, and hence have been most adversely affected (e.g., Andrew et al., 2020; Rundle et al., 2020; Scottish Government, 2020). For children with special education needs, the absence of support structures and resources has impeded learning (DfE, 202ob; Disabled Children’s Partnership, 2021; Scottish Government, 2020). Preliminary large-scale evidence suggests that children with pre-existing health conditions, children from lower SES groups, and children who have been infected with Covid-19 have experienced increased levels of anxiety, depression and post-traumatic symptoms (de Miranda et al., 2020). As reported by a global review (Loades et al., 2020), prolonged social isolation increases the risk of mental health difficulties in previously healthy children, as well. A European survey reported that parental stress from unsupported homeschooling, often alongside work, adversely impacts children's wellbeing, especially where children are exposed to unhealthy parental behaviours including conflicts and drug and alcohol use (Thorell et al., 2020). The wellbeing of many children has further suffered from increased domestic stress factors, such as financial pressure and unemployment, bereavement and domestic abuse (DfE, 2020b; Scottish Government, 2020). Pre-pandemic research highlighted the fact that parental mental health influences children's education (Loch, 2016), and this extends to more families post-pandemic. Alongside wellbeing, emerging research finds that school closures and societal lockdowns have affected children's physical health. High quality data from Slovenia, for example, indicate a ten year loss of physical health gains after only two months of school closures (Jurak et al., 
2021). While more research is needed to determine the medium and long-term effects of the pandemic on health behaviours (e.g., Viner et al., 2021), existing evidence demonstrates that addressing the effects of school closures on child health and wellbeing is central to post-pandemic educational recovery.

\section{Teachers and school leadership}

The literature reports significant teacher agency and resilience in responding to the crisis, with teachers adapting quickly despite often limited prior experience with remote teaching (Gudmundsdottir \& Hathaway, 2020; McLeod \& Dulsky, 2021; Niemi \& Kousa, 2020). Some teachers report that the circumstances have enabled a better understanding of their students (Moss et al., 2020) and generated new practices worth retaining upon the return to in-person teaching (Breeze, 2020). However, concerns exist about teachers' mental health and professional wellbeing due to increased and unpredictable workload (Aperribai et al., 2020). In England, Kim et al. (2021) identify that teachers faced with partial school reopening experienced feelings of uncertainty, practical concerns and worry for students. While further research is needed, the potential intensity and scale of the challenge to teachers and their wellbeing is significant.

Many school leaders are exhausted due to prolonged operation in crisis leadership mode (Harris \& Jones, 2020; Kelly, 2020; Thornton, 2021). Leaders report having to rapidly navigate confusing government guidelines (Beauchamp et al., 2021). They engaged in adaptive strategies, such as bridging tactics that included support-building with school networks and external agencies, brokering tactics for negotiating shared understandings and agreements with cross-boundary professional communities, and buffering tactics to mediate external pressure and filter information to school staff and community (Hulme el al., 2021). These tensions were complicated by often conflicting stakeholder responses to Covid-19 (Netolicky, 2020). The early evidence highlights the importance of support for school leaders (Harris \& Jones, 2020).

Schools face new challenges regarding the range and availability of resources to manage daily work, such as increasing use of online platforms and hardware, ensuring operational Covid-19 safety (Sharp et al., 2020), and recruiting staff to support students' new educational needs (Mental Health Foundation Scotland, 2020a). Evidence from UK school leaders shows that communications have expanded to allow informal support among teachers and families (Beauchamp et al., 2021). Teacher absences have exacerbated these challenges. In some contexts, teacher retention is an increasing issue (Darling-Hammond \& 
Hayler, 2020), although in the UK, retention and applications for initial teacher training have increased due to perceived job security (Worth \& McLean, 2020). Nonetheless, new challenges arise from organising new teachers' mentoring and training placement provision (Harju \& Niemi, 2016; Worth \& McLean, 2020). These add to Covid-19-related additional expenditure, which, alongside lost self-generated income (e.g., breakfast clubs and facility rental), is estimated to exceed $5 \%$ of UK school income (Julius et al., 2020).

\section{Figure 1}

Problem Space for Schools: Capturing, Evaluating and Acting on Local Data from Emergent Challenges

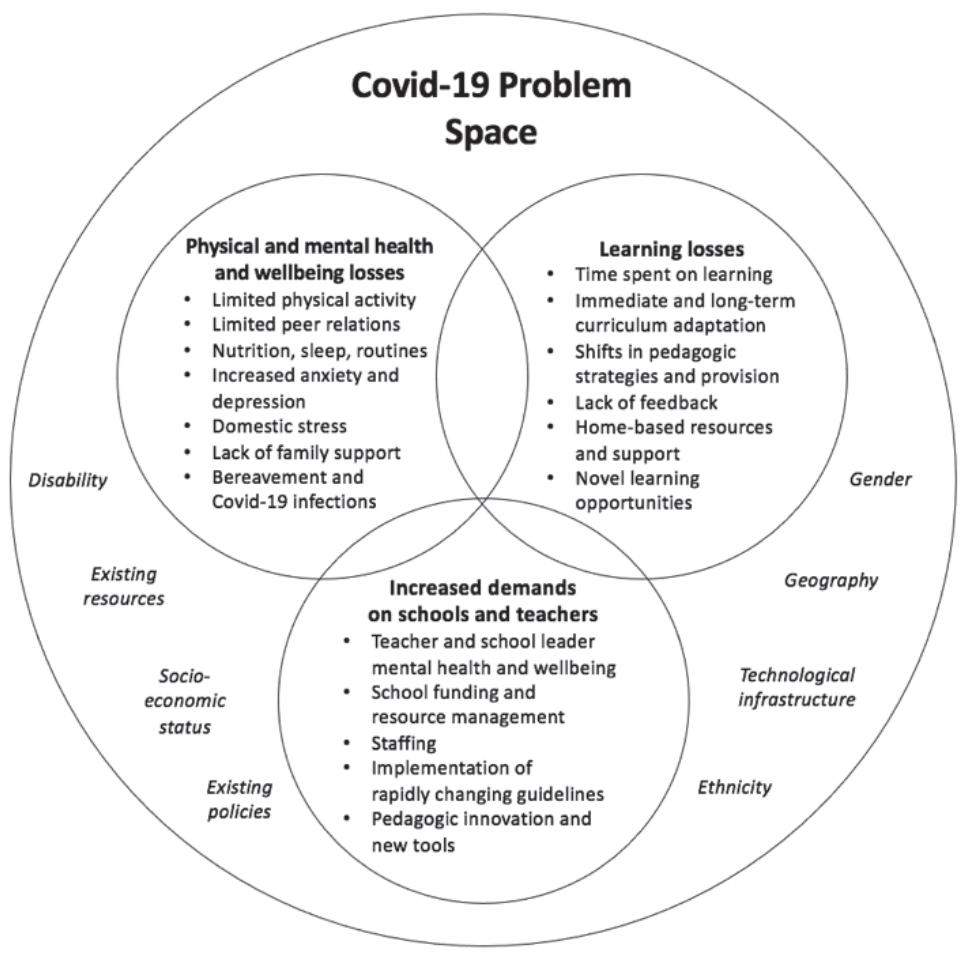

Our review illustrates the three interlocking components shaping the new problem space for education: student learning losses; student physical and mental health and wellbeing losses; and increased demands on schools and teachers. It also illustrates that researchers and educators must attend to the underlying mechanisms that shape these components and how local circumstances and schools' starting points, in intersection with existing educational 
inequalities, lead to different manifestations of these mechanisms and therefore require locally specific solutions.

Figure 1 visualises this new problem space from the perspective of a school or local setting, with the challenges and opportunities for schools situated at the centre and within existing educational inequalities and the local context. It is intended both to summarise our findings and to serve as an initial tool for practitioners to capture the nature of local problems and opportunities, thus helping to articulate the first stimulus in learning through and from Covid-19.

In interpreting the evidence of the new problem space for schools, our review also suggests where the pandemic's deeper learning potential for educators may lie. Delivering education and supporting students through the pandemic, teachers and school leaders have seen traditional boundaries of schooling (school/home; school/welfare agencies; teacher/leader) made visible and/or blurred. Working at, and crossing, boundaries is challenging (Edwards, 2012), but research suggests it makes multiple diverse tools available (Gutiérrez et al., 1999); engaging with the otherness present in/at a boundary is also itself a distinct stimulus for dialogic learning (Akkerman \& Bakker, 2011; Niemi, 2021).

\section{Conceptual tools from research on professional learning and change}

\section{Transformative agency through double stimulation}

In generating potential tensions between pre-existing desired educational outcomes and the problem space facing schools post-pandemic, and in blurring the boundaries of schooling-as-usual, the pandemic opens new learning opportunities that drive the possibility of change. In Section 3, we integrate the as-defined problem space with our research on tool-mediated professional change. While research demonstrates the potential benefits of research-informed practice development by teachers, it also shows that teachers often face practical difficulties in making use of research-based ideas (Ion et al., 2021). This will be particularly true in the pandemic/post-pandemic circumstances we have outlined in Section 2. Our research extends our understanding of, and capacity to address, this problem by specifically drawing on concepts and instruments developed and evaluated from the perspective of their capacity to support teacher-led local change.

CHAT suggests practitioners and institutions working on these boundaries can achieve transformative agency to address problems through the mechanism of double stimulation and the use and creation of locally relevant tools 
(Engeström \& Sannino, 2010). CHAT understands tools as instruments capable of doing epistemic work in a professional community/practice. While primary tools (protocols, reports) and secondary tools (thinking tools, models) describe the 'what' and 'how' of educational practice, 'where to' tools are new concepts capturing an institution's direction, helping reimagine new possibilities. The second stimulus refers to the mediating conceptual tools, which actors can adapt to analyse and work on their practice problems, the first stimulus. While, in CHAT, double stimulation is commonly evoked via intensive longitudinal researcher-supported developmental interventions, we seek to develop ways of facilitating transformative agency at scale necessitated by the pandemic.

Drawing on a wide body of research in the UK and elsewhere, we discuss research-based primary and secondary tools that can be taken up by schools as stimuli for addressing Covid-19-induced challenges to exemplify ways of adapting existing research to support scalable school-led transformative agency.

\section{Capturing student learning to inform local teaching}

During and post-pandemic, teachers and researchers need to identify and communicate local learning challenges in ways that inform teaching and local decision-making (Hofmann et al., 2021b). Our research shows that even when teachers know what their students need and can judge whether students' learning, confidence or wellbeing is improving, they find it challenging to capture those improvements as evidence (Hofmann et al., 2020). While existing standardised learning assessments can identify some learning losses, these have shortcomings. Especially when linked to high-stakes testing, such assessments can have unintended consequences, generating demotivation and anxiety, particularly for the most disadvantaged students (Barret, 2016). This raises concerns given the pandemic's mental health impact. As broad comparative policy tools, such assessments often do not disaggregate results sufficiently to provide nuanced understandings of students' learning for teachers (Azevedo et al., 2020). Crucially, they are commonly not designed to inform teaching. Moreover, as discussed, the pandemic has also impacted children's confidence, wellbeing and social opportunities. Teachers lack tools to assess these aspects of learning (Hofmann et al., 2020).

Schools need light-touch, easy-to-administer assessments addressing a broad range of knowledge/skills that are easy to interpret locally and helpful for teachers in informing teaching, such as those used in many LICs (https:// palnetwork.org/tools/). These assessments should address literacy and numeracy, non-cognitive aspects of learning and other learning conditions and goals, including sufficient disaggregation. In the epiSTEMe-project, we developed 
and tested instruments to measure student learning, attitudes and confidence in science and mathematics collaboratively with UK secondary teachers (Howe et al., 2015; Ruthven et al., 2017). These instruments have been built into an openly available self-evaluation tool for teachers (Hofmann \& Ilie, 2019). In the TEACh-project, alongside literacy and numeracy assessments, we adapted instruments from Young Lives (Iyer et al., 2017) to assess children's academic self-esteem and peer relations. These instruments were developed collaboratively with research partners in India and Pakistan, and used with a large number of children in both school and home learning settings. They were designed to be informative to teachers themselves and are also available for schools (https://www.educ.cam.ac.uk/centres/real/researchthemes/teachingandlearning/effectiveteaching/; Young Lives, n.d., a; b). We are currently conducting new research into scalable professional development interventions that can help schools assess and counteract children's sedentary lifestyles during the pandemic and capture improvements (Ryan et al., 2020).

\section{Facilitating teacher noticing regarding students' unexpected learning gaps and gains}

Children may have gained knowledge and life skills in the pandemic that they otherwise would have not have (Sabates, 2020). However, these may not be easy for teachers to identify. Our research shows that teachers often systematically miss opportunities to notice their students' unexpected knowledge and learning capabilities, especially in low-SES settings (Hennessy et al., 2016; Rainio \& Hofmann, 2021). Moreover, teachers' collective conceptualisations of students influence teacher noticing, often limiting their perceptions of student capabilities (Rainio \& Hofmann, 2015, 2021). This can work both ways: teachers miss learning gaps in high-attaining students and overlook existing knowledge/ skill in low-attaining students (Tiong, 2021). While opportunities to discuss their assessments of students with colleagues are central, these do not automatically lead to teacher learning and noticing: unexpected learning patterns are often explained away or not addressed in collaborative planning discussions. This can be helpful insofar as it serves the purpose of making work manageable through reducing complexity and facilitating quick solutions under time pressure. However, these assumptions have been shown to be consequential for students' classroom learning, leading to missed opportunities to support learning (Horn \& Kane, 2015; Wilhelm et al., 2017).

Teachers need tools to notice and systematically explore unexpected observations. Our own research, as well as that of others, suggests the importance 
of stimulating teachers to share concrete representations of practice with colleagues, combined with the explicit conceptual ideas of slowing down and 'staying with' surprising or puzzling data and purposefully avoiding premature explanations and closure or rushing to solutions (Horn \& Kane, 2015; Rainio \& Hofmann, 2021). Such opportunities can be facilitated at scale by trialling new classroom interventions, which we have shown nearly always leads to surprise about what students know and can do (Hofmann, 2020a). This finding, observed by our teacher collaborators themselves, has been replicated across countries from the UK to Scandinavia and Africa in research on school interventions. The pandemic has necessitated the trialling of new ways of teaching. Schools should ensure they capitalise on the transformative professional learning potential this offers. Opportunities to stay with such new surprising insights can be supported by fit-for-purpose assessment tools, structured peer facilitation (Hassler et al., 2018) and organisational routines that create regular spaces for self-reflection, working out changes in practice and stabilising those changes over time (Sherer \& Spillane, 2011). In order to effectively facilitate generative dialogues and stabilisation of new practices, however, such organisational routines need to be enriched through collaboration and trialling tools (Dickens, 2021; Hassler et al., 2020; Marfan, 2021; Rainio \& Hofmann, 2021). We next discuss some examples.

\section{Implementing classroom interventions}

Research shows that teachers often locate themselves as unagentic visà-vis change (Horn \& Kane, 2015; Rainio \& Hofmann, 2015, 2021). This deters change efforts and decreases teacher wellbeing (Soini et al., 2016). Having to trial new interventions in the workplace as part of professional development courses leads to greater awareness of one's agency to effect change (Rainio \& Hofmann, 2021). Herein lies the paradox of agency of professional change (Hofmann, 202ob). In order to enable unsupported trialling at scale, we developed a starting small approach for teachers to try out dialogic pedagogy (a well-evidenced approach supporting student learning, which teachers often find challenging, cf., Ruthven et al., 2017). Our approach was developed in collaboration with UK primary and secondary teachers and involves a tool teachers can use without researcher support to capture new insights from a single-lesson trial (Hofmann \& Ilie, 2019, 2021). Our proof-of-concept study has demonstrated its potential for new insights (Hofmann \& Ilie, 2021), and we are currently conducting research about the initial conditions and mechanisms of getting new pedagogic interventions off the ground at scale. 
Our research has further demonstrated the often hidden role classroom norms play in shaping educational practice (Hofmann \& Ruthven, 2018), revealing the multi-dimensional nature of interaction norms that guide classroom practice. Surface level norms, such as 'listening to others', can be enunciated in terms of multiple underlying rationales and, unless explicitly addressed, can lead to the superficial adoption of new interventions. Adapting this research, we have developed a tool for dialogic teaching interventions, the People, Talk, Ideas tool (Hofmann \& Ilie, 2019), which supports in-depth classroom discussions. In addition, it can help teachers develop tools to address implicit normative aspects of teaching and learning that hinder change. The tool has been trialled and productively used by numerous UK and other European primary and secondary teachers across multiple projects supporting change efforts (Hofmann et al., 2021a).

Finally, a leadership and collaboration tool we developed, the Who, What, Why and When tool (Hofmann \& Vermunt, 2020; Hofmann, 2020b), can help practitioners identify and map out expected and unexpected 'others' who can support their change efforts in different ways. In highlighting latent knowledge and support available within organisations, this tool facilitates relational agency, professionals' capability of working productively with others to support change (Edwards, 2012).

A number of these tools have been integrated into an implementation model (Hofmann, 2020a) that has been trialled collaboratively with UK schools and operationalised into the ED:TALK Dialogue and Evidence Toolkit (Hofmann \& Ilie, 2019, 2021), which has been developed to support teachers and schools in developing research-informed teaching and learning. The Toolkit is designed to offer an off-the-shelf tool to support school-led efforts for pedagogic innovation adaptable to existing curricula and local learning needs. It offers teachers the means to design, plan and evaluate teaching improvement projects of their choice, including support for teacher noticing and collaboration.

While many of the tools discussed here are concrete objects, assessments and thinking tools that teachers can download and readily use, they can also support schools' own second stimulus tool generation. Taken as a starting point, these tools can be adapted by teachers for their own local setting via collaboration and dialogue. They need to be filled with concrete local detail (and accountability) and the test of their effectiveness is in their use in each local setting. In the process, the original tools can be transformed and shared with others. Ultimately, these tools and others like them can help participants develop new 'where to' tools (cf. Engeström, 2001), actionable concepts to reimagine their goals for teaching and learning and the ways of achieving these goals. 


\section{Discussion and conclusion}

The Covid-19 pandemic has created an unprecedented global educational crisis disrupting the lives and learning of millions of children worldwide and has pushed teachers and schools beyond the boundaries of practice-as-usual. The present paper advances our understanding of scalable, evidence-informed approaches and tools to facilitate sustained transformative agency in schools to address learning losses and opportunities emerging from the pandemic. It does so by conceptualising transformative agency through cultural-historical activity theory, as achieved through the mechanism of double stimulation and combining it with a body of research on scalable change tools for schools. Emerging data points to agentic emergency responses by schools and teachers, but also highlights perceived difficulties in addressing the pandemic's impact. The literature suggests that we now need new learning and collaboration opportunities for teachers to develop possibility perspectives and to capture, develop and sustain what is most promising from these novel pedagogic responses; it also acknowledges gaps in our understanding of the mechanisms of facilitating such transformative learning at scale (Darling-Hammond \& Hyler, 2020; Hofmann, 2020a; Kennedy, 2019). While sustaining schools' agency requires support through innovative policies and associated financial, political and multi-professional resources, we also need research-informed approaches and tools that can support schools in using these resources locally to generate and disseminate change (cf. Niemi, 2021).

The present paper has mapped the first stimulus problem space facing teachers and schools, contributing to the identification of the possible range of factors influencing local learning loss, highlighting the under-researched role of the pandemic's impact on children's health and wellbeing in forming learning conditions, and depicting how the blurring of school boundaries has impacted teachers' work. It extends the existing evidence-base from the pandemic by advancing understandings of the underlying factors influencing and mediating surface-level manifestations of problems, which will affect pandemic responses and future research.

Secondly, we have identified adaptable research-based tools to enable locally responsive school-based educational innovation in response to the pandemic. We have illustrated tools to identify unexpected learning gaps and gains, to facilitate teacher noticing and collaboration, and to support the implementation of pedagogic innovations. Besides being a direct contribution to teacher learning, these tools, as second stimuli, can contribute to facilitating transformative agency at scale, while also providing new conceptual tools for future research on enabling pedagogic change. Our research advances our 
understanding of scalable applications of CHAT (cf. Edwards, 2008) as a novel way of enabling educational change post-pandemic.

Our research also advances our understandings of the mechanisms of teacher learning (cf. Opfer \& Pedder, 2011) during a pandemic more broadly, and suggests ways of capturing these mechanisms. The pandemic has necessitated the development and trialling of entirely new ways of teaching, generating a unique professional learning opportunity. We have discussed how trialling new approaches and working on new boundaries enables novel insights into practice, which is a key mechanism of sustainable teacher learning. Our second stimulus tools not only enable pedagogic innovation and accountability, but also help teachers and schools materialise new insights in new practices, in order to avoid these new learnings from 'slipping away' post-pandemic. Collaboratively examining such new insights can contribute to expanding teachers' horizon of possibility (Engeström, 2001; Rainio \& Hofmann, 2021). Together with the tools we have described, the new pandemic insights can prompt new sense-making regarding novel directions for teaching and learning in school. In this way, our research contributes to schools' possibility of collectively reimagining local practice to address the challenges arising from the Covid-19 pandemic. By enabling teachers to capture and communicate their learning of what matters, our research also contributes to the need to share schools' learning across institutions and contexts (Darling-Hammond \& Hyler, 2020; Hofmann et al., 2020; Niemi, 2021).

Our work invites future research on:

- Mechanisms facilitating schools' take-up and implementation of research-based pedagogic tools and the stabilisation of such tools into sustainable new practices at scale; their impact on teacher professional agency and student learning;

- School-based scalable interventions to support children's learning conditions, including health and wellbeing post-pandemic;

- Mechanisms of school-led teacher learning from boundary-crossing professional dialogues.

The present paper offers a foundation for such work and a way of integrating these strands of theorising educational responses to the pandemic.

\section{Acknowledgement}

The work reported was supported by several sources of funding. The Economic and Social Research Council provided funding for the epiSTEMe project [grant number RES-179-25-0003] and, together with DfID, for the TEACh project 
[ES/Moo5445/1], and through two Impact Acceleration Account grants via the University of Cambridge. Further research discussed was funded by the Cambridge University Health Partners and the Commonwealth Education Trust. The $\mathrm{PhD}$ research of authors 2-7 was funded by the Faculty of Education, University of Cambridge; Economic and Social Research Council [ES/Pooo738/1]; Agencia Nacional de Investigación y Desarrollo (ANID), Cambridge Trust; Economic and Social Research Council [ES/Pooo738/1] and MRC Epidemiology Unit; Yayasan Khazanah, Cambridge Trust; Guy's and St Thomas' Charity, UK [TCF180902]; and the LEGO Foundation. We thank Dr Lisa Beth Walker for her comments on an earlier version of this manuscript. Thanks are also due to the teachers who engaged with the research projects and tools discussed.

\section{References}

Akkerman, S., \& Bakker, A. (2011). Boundary crossing and boundary objects. Review of Educational Research, 81(2), 132-169. https://doi.org/10.3102/0034654311404435

Alam, A., \& Tiwari, P. (2020). Putting the 'learning' back in remote learning. UNICEF Office of Global Insight and Policy. https://www.unicef.org/globalinsight/sites/unicef.org.globalinsight/files/2020-06/ UNICEF-Global-Insight-remote-learning-issue-brief-2020.pdf

Alban Conto, C., Akseer, S., Dreesen, T., Kamei, A., Mizunoya, S., \& Rigole, A. (2020). COVID-19: Effects of school closures on foundational skills (Report No. WP 2020-13). UNICEF Office of Research - Innocenti. https://www.unicef-irc.org/publications/pdf/COVID-19_Effects_of_School_Closures_on_ Foundational_Skills_and_Promising_Practices_for_Monitoring_and_Mitigating_Learning_Loss.pdf Andrew, A., Cattan, S., Costa Dias, M., Farquharson, C., Kraftman, L., Krutikova, S., Phimister, A., \& Sevilla, A. (2020). Inequalities in children's experiences of home learning during the COVID-19 Lockdown in England*. Fiscal Studies, 41(3), 653-683. https://doi.org/10.1111/1475-5890.12240 Angrist, N., de Barros, A., Bhula, R., Chakera, S., Cummiskey, C., DeStefano, J., Floretta, J., Kaffenberger, M., Piper, B., \& Stern, J. (2021). Building back better to avert a learning catastrophe: Estimating learning loss from COVID-19 school shutdowns in Africa and facilitating short-term and long-term learning recovery. International Journal of Educational Development, 84, 1-14. https://doi. org/10.1016/j.ijedudev.2021.102397 Aperribai, L., Cortabarria, L., Aguirre, T., Verche, E., \& Borges, Á. (2020). Teacher's physical activity and mental health during lockdown due to the COVID-2019 pandemic. Frontiers in Psychology, 11(November), 1-14. https://doi.org/10.3389/fpsyg.2020.577886 ASER. (2020) Annual status of education report (rural) 2020 wave. http://img.asercentre.org/docs/ ASER\%202020/ASER\%202020\%20REPORT/aser202ofullreport.pdf Azevedo, J. P., Hasan, A., Goldemberg, D., Iqbal, S. A., \& Heven, K. (2020). Simulating the potential impacts of Covid-19 school closures on schooling and learning outcomes. World Bank Group: Education. http://pubdocs.worldbank.org/en/798061592482682799/covid-and-education-June17-r6.pdf 
Ball, S., Maguire, M., \& Braun, A. (2012). How schools do policy. Policy enactments in secondary schools. Routledge.

Barret, A. (2016). Measuring learning outcomes and education for sustainable development: The new education development goal. In W. C. Smith (Ed.), The global testing culture: Shaping education policy, perceptions, and practice. oxford studies in comparative education, 25(1), 101-114). Symposium Books. Bayrakdar, S., \& Guveli, A. (2020). Inequalities in home learning and schools' provision of distance teaching during school closure of COVID-19 lockdown in the UK (Working Paper No. 2020-09; IPER Working Paper Series). Institute for Social and Economic Research. https://www.iser.essex.ac.uk/ research/publications/working-papers/iser/2020-09.pdf

Beauchamp, G., Hulme, M., Clarke, L., Hamilton, L., \& Harvey, J. A. (2021). 'People miss people’: A study of school leadership and management in the four nations of the United Kingdom in the early stage of the COVID-19 pandemic. Educational Management Administration \& Leadership. https:// doi.org/10.1177/1741143220987841

Bešter, R., \& Pirc, J. (2020). Impact of remote learning during the Covid-19 lockdown on Roma pupils in Slovenia. Journal of Ethnic Studies, 85, 139-164. https://doi.org/10.36144/RiG85.dec20.139-164 Breeze, H. (2020). The impact of COVID-19 on early career teachers. The RSA blog. https://www. thersa.org/blog/2020/o6/early-career-teachers-covid Crenna-Jennings, W., Perera, N., \& Sibieta, L. (2021). Education recovery and resilience in England. Phase 1 report. Education Policy Institute. https://epi.org.uk/publications-and-research/educationrecovery-and-resilience-in-england/

Cullinane, C., \& Montacute, R. (2020). COVID-19 and social mobility impact brief \#1(No. 1; COVID-19 and social mobility). Sutton Trust. https://www.suttontrust.com/wp-content/uploads/2020/04/ COVID-19-Impact-Brief-School-Shutdown.pdf

Darling-Hammond, L., \& Hyler, M. E. (2020). Preparing educators for the time of COVID... and beyond. European Journal of Teacher Education, 43(4), 457-465. https://doi.org/10.1080/02619768.20 20.1816961

Datnow, A., \& Park, V. (2009). Conceptualizing policy implementation. In G. Sykes, B. Schneider, D. Plank, \& T. Ford (Eds.), Handbook of education policy research (pp. 348-361). Routledge. de Miranda, D. M, da Silva Athanasio, B., Sena Oliveira, A. C., \& Simoes-e-Silva, A. C. (2020). How is COVID-19 pandemic impacting mental health of children and adolescents? International Journal of Disaster Risk Reduction, 51, 101845. https://doi.org/10.1016/j.ijdrr.2020.101845 Department for Education. (2020a). Attendance in education and early years settings during the coronavirus outbreak: 23 March to 11 June 2020. UK Government. https://www.gov.uk/government/ publications/coronavirus-covid-19-attendance-in-education-and-early-years-settings Department for Education. (2020b). Effect of pandemic on children's wellbeing revealed in new report (DFE-RR-999; Government Social Research). UK Government. https://www.gov.uk/government/ news/effect-of-pandemic-on-childrens-wellbeing-revealed-in-new-report

Dickens, S. (2021). Knowledge and curriculum: A tool for reflective practice. Manuscript in preparation. 
Disabled Children's Partnership. (2021). \#LeftInLockdown - Parent carers' experiences of lockdown.

Disabled Children's Partnership. https://disabledchildrenspartnership.org.uk/wp-content/ uploads/2020/o6/LeftInLockdown-Parent-carers'-experiences-of-lockdown-June-2020.pdf Education Endowment Foundation (EEF). (2020, June 2). Best evidence on impact of Covid-19 on pupil attainment. https://educationendowmentfoundation.org.uk/eef-support-for-schools/covid-19resources/best-evidence-on-impact-of-school-closures-on-the-attainment-gap/ Edwards, A. (2012). The role of common knowledge in achieving collaboration across practices. Learning, Culture and Social Interaction, 1(1), 22-32. https://doi.org/10.1016/j.lcsi.2012.03.003 Edwards, A. (2008). Activity theory and small-scale interventions in schools. Journal of Educational Change 9(4), 375-378. https://doi.org/10.1007/s10833-008-9085-7

Eickelmann, B., \& Drossel, K. (2020). Schule auf Distanz: Perspektiven und Empfehlungen für den neuen Schulalltag [School remotely: Perspectives and recommendations for the new situation in schools]. Vodafone Stiftung Deutschland. https://www.vodafone-stiftung.de/wp-content/ uploads/2020/05/Vodafone-Stiftung-Deutschland_Studie_Schule_auf_Distanz.pdf Eivers, E., Worth, J., \& Ghosh, A. (2020). Home learning during Covid-19 NFER. https://www.nfer. ac.uk/home-learning-during-covid-19-findings-from-the-understanding-society-longitudinal-study/ Engeström, Y. (2001). Expansive learning at work: Toward an activity theoretical reconceptualization. Journal of Education and Work, 14(1), 133-156. https://doi.org/10.1080/13639080020028747 Engeström, Y., \& Sannino, A. (2010). Studies of expansive learning: Foundations, findings and future challenges. Educational Research Review, 5(1), 1-24. https://doi.org/10.1016/j.edurev.2009.12.002 Ermenc, K., \& Urbančič, M. (2021). Researching education during a pandemic. Sodobna pedagogika, 72(1), 264-268. https://www.sodobna-pedagogika.net/en/archive/load-article/?id=1810 Faught, E. L., Qian, W., Carson, V. L., Storey, K. E., Faulkner, G., Veugelers, P. J., \& Leatherdale, S. T. (2019). The longitudinal impact of diet, physical activity, sleep, and screen time on Canadian adolescents' academic achievement: An analysis from the COMPASS study. Preventive Medicine, 125, 24-31. https://doi. org/10.1016/j.ypmed.2019.05.007

Green, F. (2020). Schoolwork in lockdown. (Research Paper No. 67). Centre for Learning and Life Chances in Knowledge Economies and Societies (LLAKES). https://doi.org/10.5255/UKDA-

SN-8644-1

Gudmundsdottir, G. B., \& Hathaway, D. M. (2020). "We always make it work": Teachers' agency in the time of crisis. Journal of Technology and Teacher Education, 22(2), 239-250.

Gustafsson, M., \& Nuga, C. (2020). How is the COVID-19 pandemic affecting educational quality in South Africa? Insight Briefs. https://cramsurvey.org/wp-content/uploads/2020/o7/Gustafsson.-Nuga.How-is-the-COVID-19-pandemic-affecting-educational-quality-in-South-Africa_-1.pdf Gutiérrez, K. D., Baquedano-López, P., \& Tejeda, C. (1999). Rethinking diversity: Hybridity and hybrid language practices in the third space. Mind, Culture, and Activity, 6(4), 286-303. https://doi. org/10.1080/10749039909524733

Harju, V., \& Niemi, H. (2016). Newly qualified teachers' needs of support for professional competences in four European countries: Finland, the United Kingdom, Portugal, and Belgium. 
CEPS Journal, 6(3), 77-10o. https://ojs.cepsj.si/index.php/cepsj/article/view/66/27

Harris, A., \& Jones, M. (2020). COVID 19 - school leadership in disruptive times. School Leadership \& Management, 40(4), 243-247. https://doi.org/10.1080/13632434.2020.1811479

Hassler, B., Hennessy, S., \& Hofmann, R. (2020). OER4Schools: Outcomes of a sustained professional development intervention in Sub-Saharan Africa. Frontiers in education (Section Teacher Education), 5. https://doi.org/10.3389/feduc.2020.00146

Hassler, B., Hennessy, S., \& Hofmann, R. (2018). Sustaining and scaling pedagogic innovation in Sub-Saharan Africa: Grounded insights for teacher professional development. Journal of Learning for Development, 5(1), 58-78. https://jl4d.org/index.php/ejl4d/article/view/264

Hennessy, S., Haßler, B., \& Hofmann, R. (2016). Pedagogic change by Zambian primary school teachers participating in the OER4Schools professional development programme for one year. Research Papers in Education, 31(4), 399-427. https://doi.org/10.1080/02671522.2015.1073343 Hofmann, R. (2020a, April). Re-conceptualising the mechanisms of change in professional learning and practice. [Individual paper]. American Educational Research Association (AERA) Conference 2021, conference cancelled.

Hofmann, R. (2020b). The three paradoxes of leadership: Overcoming barriers that stop new leaders from delivering change. UK Cabinet Office Thinkpiece series. https://assets.publishing.service.gov. uk/government/uploads/system/uploads/attachment_data/file/926862/NLC-thinkpiece-DevelopingLeaders-HOFMANN.pdf

Hofmann, R., \& Ilie, S. (2019). ED:TALK Evidence and Dialogue Toolkit. Faculty of Education, University of Cambridge. http://edtoolkit.educ.cam.ac.uk/

Hofmann, R., \& Ilie, S. (2021, April). Developing and evaluating a research-based scalable implementation toolkit for dialogic teaching in disadvantaged schools [Individual paper]. American Educational Research Association (AERA) Conference 2021, held virtually.

Hofmann, R., Ilie, S., \& Curran, S. (2020). Evidence based practice fund evaluation. Final report to the Department for Education Eastern Opportunity Areas.

Hofmann, R., Ilie, S., \& Broeks, M. (2021b). Identifying key impacts of the Fenland and East Cambridgeshire Opportunity Area: Evidence review. Commissioned report to the UK Department for Education Fenland and East Cambridgeshire Opportunity Area.

Hofmann, R., \& Ruthven, K. (2018). Operational, interpersonal, discussional and ideational dimensions of classroom norms for dialogic practice in school mathematics. British Educational Research Journal, 44(3), 496-514. https://doi.org/10.1002/berj.3444

Hofmann, R., \& Vermunt, J. D. (2021). Professional learning, organisational change and clinical leadership development outcomes. Medical Education, 55(2), 252-265. https://doi.org/10.1111/medu.14343 Hofmann, R., Vrikki, M., \& Evagorou, M. (2021a) Engaging teachers in dialogic teaching as a way to promote cultural literacy learning: A Reflection on teacher professional development. In F. Maine \& M. Vrikki (Eds.), Dialogue for intercultural understanding placing cultural literacy at the heart of learning (pp. 135-148). Springer Nature.

Honig, M. (2006). Complexity and policy implementation: Challenges and opportunities for the 
field. In M. Honig (Ed.), New directions in education policy implementation. Confronting complexity (pp. 1-24). State University of New York Press.

Horn, I. S., \& Kane, B. D. (2015). Opportunities for professional learning in mathematics teacher workgroup conversations: Relationships to instructional expertise. Journal of the Learning

Sciences, 24(3), 373-418. https://doi.org/10.1080/10508406.2015.1034865

Howe, C., Luthman, S., Ruthven, K., Mercer, N., Hofmann, R., Ilie, S., \& Guardia, P. (2015). Rational number and proportional reasoning in early secondary school: Towards principled improvement in mathematics.

Research in Mathematics Education, 17(1), 38-56. https://doi.org/10.1080/14794802.2015.1019914

Huber, S. G., Günther, P. S., Schneider, N., Helm, C., Schwander, M., Schneider, J. A., \& Pruitt, J. (2020). COVID-19 - aktuelle Herausforderungen in Schule und Bildung [COVID-19 - Current challenges in schools and education]. Waxmann.

https://www.waxmann.com/index.php?eID=download\&buchnr $=4216$

Hulme, M., Beauchamp, G., Clarke, L., \& Hamilton, L. (2021). Collaboration in times of crisis: Leading UK schools in the early stages of a pandemic. Leadership and Policy in Schools. https://doi.or $\mathrm{g} / 10.1080 / 15700763.2021 .1917623$

Ion, G., Suárez, C. I., \& Diaz Vicario, A. (2021). Evidence-informed educational practice in Catalan education: From public agenda to teachers' practice. CEPS Journal, 11(2), 37-57. https://www.cepsj.si/ index.php/cepsj/article/view/1062/469

Iyer, P., Azubuike, O. B., \& Rolleston, C. (2017, Nov). Young lives school survey, 2016 -17: Evidence from Vietnam. Young Lives. https://www.younglives.org.uk/sites/www.younglives.org.uk/files/YLCountryReport-Vietnam-Nov17_o.pdf

Julius, J., Hillary, J., \& Faulkner-Ellis, H. (2020). Schools' responses to Covid-19. NFER. https://www. nfer.ac.uk/media/4225/the_implications_of_covid_19_on_the_school_funding_landscape.pdf Jurak, G., Morrison, S. A., Kovač, M., Leskošek, B., Sember, V., Strel, J., \& Starc, G. (2021). A COVID-19 crisis in child physical fitness: Creating a barometric tool of public health engagement for the Republic of Slovenia. Frontiers in Public Health, 9(179), 1-7. https://doi.org/10.3389/ fpubh.2021.644235

Kennedy, M. M. (2019). How we learn about teacher learning. Review of Research in Education, 43(1), 138-162. https://doi.org/10.3102/0091732X19838970

Kelly, H. (2020, December 2). How is the stress of Covid-19 affecting school leaders? TES. https:// www.tes.com/news/how-stress-covid-19-affecting-school-leaders

Kim, L. E., Leary, R., \& Asbury, K. (2021). Teachers' narratives during COVID-19 partial school reopenings: An exploratory study, Educational Research. https://doi.org/10.1080/oo131881.2021.1918014 Loades, M. E., Chatburn, E., Higson-Sweeney, N., Reynolds, S., Shafran, R., Brigden, A., Linney, C., McManus, M. N., Borwick, C., \& Crawley, E. (2020). Rapid systematic review: The impact of social isolation and loneliness on the mental health of children and adolescents in the context of COVID-19. Journal of the American Academy of Child and Adolescent Psychiatry, 59(11), 1218-1239. https://doi.org/10.1016/j.jaac.2020.05.009 Loch, U. (2016). The family as a place of education. Between a school-centred focus on education 
and family needs. CEPS Journal, 6(4), 93-113. https://www.pedocs.de/volltexte/2017/12760/pdf/ cepsj_2016_4_Loch_Family_as_a_place_of_education.pdf

Lucas, M., Nelson, J., \& Sims, D. (2020). Schools responses to Covid-19. NFER. https://www.nfer.ac.uk/ media/4073/schools_responses_to_covid_19_pupil_engagement_in_remote_learning.pdf Marfan, J. (2021). Schools deciding the purpose of Education: Policy enactment in a context of educational reform hybridisation. Manuscript in preparation.

McAleavy, T. (2020). Learning renewed: A safe way to reopen schools in the Global South. Education Development Trust. https://www.educationdevelopmenttrust.com/EducationDevelopmentTrust/ files/b4/b4f1729a-8058-4912-af2e-fbe8304c3199.pdf

McLeod, S., \& Dulsky, S. (2021). Resilience, reorientation, and reinvention: School leadership during the early months of the COVID-19 pandemic. Front. Educ., 6(637075), https://doi.org/10.3389/ feduc.2021.637075

Mental Health Foundation Scotland. (2020). Children and young people's mental health during Covid-19 policy statement. Mental Health Foundation Scotland. https://www.mentalhealth.org.uk/ publications/children-and-young-people\%E2\%80\%99s-mental-health-during-covid-19-policystatement

Middleton, K. (2020). The longer-term impact of COVID-19 on K-12 student learning and assessment. Educational Measurement: Issues and Practice, 39(3), 41-44. https://doi.org/10.1111/ emip. 12368

Montacute, R., \& Cullinane, C. (2021). Learning in lockdown [Research brief]. The Sutton Trust. https://www.suttontrust.com/wp-content/uploads/2021/o1/Learning-in-Lockdown.pdf Moss, G., Allen, R., Bradbury, A., Duncan, S., Harmey, S., \& Levy, R. (2020). Primary teachers' experience of the COVID-19 lockdown - Eight key messages for policymakers going forward. UCL Institute of Education. https://discovery.ucl.ac.uk/id/eprint/10103669/ Netolicky, D. M. (2020). School leadership during a pandemic: Navigating tensions. Journal of Professional Capital and Community, 5(3/4), 391-395. https://doi.org/10.1108/JPCC-05-2020-0017 Niemi, H. (2021). Education reforms for equity and quality. An analysis from an educational ecosystem perspective with a special reference to Finnish educational transformation. CEPS Journal, 11(2), 13-35. https://www.cepsj.si/index.php/cepsj/article/view/110o/468

Niemi, H. M., \& Kousa, P. (2020). A case study of students' and teachers' perceptions in a Finnish high school during the COVID pandemic. International Journal of Technology in Education and Science, 4(4), 352-369. https://doi.org/10.46328/ijtes.v4i4.167 OECD. (n.d.). School education during COVID-19: Were teachers and students ready? https://www. oecd.org/education/coronavirus-education-country-notes.htm

Ofqual. (2020, August 3). Exams and assessments in 2021. Gov.UK. https://www.gov.uk/government/ news/exams-and-assessments-in-2021

Ofsted. (2021, February 18). Remote education research.https://www.gov.uk/government/publications/ remote-education-research/remote-education-research

Ofsted. (2020a). COVID-19 series: Briefing on schools, September 2020. Ofsted. https://assets. 
publishing.service.gov.uk/government/uploads/system/uploads/attachment_data/file/92467o/ Schools_briefing_COVID-19_series_Sept-20202.pdf

Ofsted. (2020b). COVID-19 series: Briefing on schools, October 2020. Ofsted. https://assets.publishing. service.gov.uk/government/uploads/system/uploads/attachment_data/file/93349o/COVID-19_ series_briefing_on_schools_October_2020.pdf Ofsted. (2020c). COVID-19 series: Briefing on schools, November 2020. Ofsted. https://assets. publishing.service.gov.uk/government/uploads/system/uploads/attachment_data/file/943732/ COVID-19_series_briefing_on_schools_November_2020.pdf Opfer, V. D., \& Pedder, D. (2011). Conceptualizing teacher professional learning. Review of Educational Research, 81(3), 376-407. https://doi.org/10.3102/0034654311413609 Patrinos, H., \& Donnelly, R. (2021). Learning loss during COVID-19: An early systematic review. Research Square. https://doi.org/10.21203/rs.3.rs-518655/v1

Radhakrishnan, K., Angrist, N., Bergman, P., Cullen, C., Matsheng, M., Ramakrishnan, A., Sabarwal, S., \& Sharma, U. (2021). Learning in the time of COVID-19: Insights from Nepal. World Bank. https:// openknowledge.worldbank.org/bitstream/handle/10986/35384/Learning-in-the-Time-of-COVID-19Insights-from-Nepal.pdf? sequence $=1$ \&isAllowed $=y$ Rainio, A. P., \& Hofmann, R. (2021). Teacher professional dialogues during a school intervention: From stabilization to possibility discourse through reflexive noticing. Journal of the Learning Sciences. https://doi.org/10.1080/10508406.2021.1936532

Rainio, A. P., \& Hofmann, R. (2015). Transformations in teachers' discourse about their students during a school-led pedagogic intervention. The European Journal of Social \& Behavioural Sciences, 13(2), 1815. http://dx.doi.org/10.15405/ejsbs.163

Rundle, A. G., Park, Y., Herbstman, J. B., Kinsey, E. W., \& Wang, Y. C. (2020). COVID-19-related school closings and risk of weight gain among children. Obesity, 28(6), 1008-1009. 10.1002/oby.22813 Ruthven, K., Mercer, N., Taber, K. S., Guardia, P., Hofmann, R., Ilie, S., Luthman, S., \& Riga, F. (2017). A research-informed dialogic-teaching approach to early secondary school mathematics and science: The pedagogical design and field trial of the epiSTEMe intervention. Research Papers in Education, 32(1), 18-40. https://doi.org/10.1080/02671522.2015.1129642

Ryan, M., Alliott, O., Hofmann, R., \& van Sluijs, E. A systematic review of staff training in school-based interventions targeting student physical activity behaviour. PROSPERO 2020 CRD42020180624. https://www.crd.york.ac.uk/prospero/display_record.php?ID=CRD42020180624 Sabates, R., Carter, E., \& Stern, J. M. (2021). Using educational transitions to estimate learning loss due to COVID-19 school closures: The case of Complementary Basic Education in Ghana. International Journal of Educational Development, 82, 1-9. https://doi.org/10.1016/j.ijedudev.2021.102377 Sabates, R. (2020, April 16). Think local: Support for learning during COVID-19 could be found from within communities. UKFIET The Education and Development Forum. https://www.ukfiet.org/2020/ think-local-support-for-learning-during-covid-19-could-be-found-from-within-communities/ Sannino, A. (2015). The principle of double stimulation: A path to volitional action. Learning, Culture and Social Interaction, 6, 1-15. https://doi.org/10.1016/j.lcsi.2015.01.001 
Scottish Government. (2020). Coronavirus (COVID-19): Impact on children, young people and families - evidence summary (PPDAS790346 (11/20); Social Research Series). APS Group Scotland. https:// www.gov.scot/publications/report-covid-19-children-young-people-families-october-202O-evidencesummary/

Sharp, C., Nelson, J., Lucas, M., Julius, J., McCrone, T., \& Sims, D. (2020). Schools' responses to Covid-19. NFER. https://www.nfer.ac.uk/media/4119/schools_responses_to_covid_19_the_ challenges_facing_schools_and_pupils_in_september_2020.pdf

Sherer, J. Z., \& Spillane, J. P. (2011). Constancy and change in work practice in schools: The role of organizational routines. Teachers College Record, 113(3), 611-657. https://www.tcrecord.org/Content. asp?Content $\mathrm{Id}=16065$

Sibieta, L., \& Robinson, D. (2020). School attendance and lost schooling across England since full reopening. Education Policy Institute. https://epi.org.uk/wp-content/uploads/2020/12/ANALYSIS_ School-attendance-and-lost-schooling-across-England.pdf

Soini, T., Pietarinen, J., \& Pyhältö, K. (2016). What if teachers learn in the classroom? Teacher Development, 20(3), 380-397. https://doi.org/10.1080/13664530.2016.1149511

Thorell, L. B., Skoglund, C., de la Peña, A. G., Baeyens, D., Fuermaier, A. B. M., Groom, M. J., Mammarella, I. C., van der Oord, S., van den Hoofdakker, B. J., Luman, M., de Miranda, D. M., Siu, A. F. Y., Steinmayr, R., Idrees, I., Soares, L. S., Sörlin, M., Luque, J. L., Moscardino, U. M., Roch, M., ... Christiansen, H. (2021). Parental experiences of homeschooling during the COVID-19 pandemic: Differences between seven European countries and between children with and without mental health conditions. European Child \& Adolescent Psychiatry. https://doi.org/10.1007/s00787-020-01706-1 Thornton, K. (2021). Leading through COVID-19: New Zealand secondary principals describe their reality. Educational Management Administration \& Leadership, 1-17. https://doi.org/10.1177/1741143220985110 Tiong, N. D. (2021). Doing dialogue differently: Case studies of teacher collaborative discourse in Malaysian secondary schools [Unpublished Doctoral thesis]. University of Cambridge. UNESCO. (2021, January). Global monitoring of school closures caused by COVID-19. UNESCO. https://en.unesco.org/covidig/educationresponse UNESCO. (2020). COVID 19 response - remediation: Helping students catch up on lost learning, with a focus on closing equity gaps. UNESCO. https://unesdoc.unesco.org/ark:/48223/pfoooo373766 UNESCO, UNICEF, \& World Bank. (2020). What have we learnt? Overview of findings from a survey of ministries of education on national responses to COVID-19. UNESCO, UNICEF, and World Bank. https://data.unicef.org/resources/national-education-responses-to-covid19/ Viner, R. M., Russell, S., Saulle, R., Croker, H., Stansfield, C., Packer, J., ... \& Minozzi, S. (2021). Impacts of school closures on physical and mental health of children and young people: A systematic review. MedRxiv. Vuorikari, R., Velicu, A., Chaudron, S., Cachia, R., \& Di Gioia, R. (2020). How families handled emergency remote schooling during the Covid-19 lockdown in spring 2020. Joint Research Centre of the European Commission. https://publications.jrc.ec.europa.eu/repository/handle/JRC122303 Wilhelm, A. G., Munter, C., \& Jackson, K. (2017). Examining relations between teachers' explanations of sources of students' difficulty in mathematics and students' opportunities to learn. The Elementary 
School Journal, $117(3), 345-370$.

Worth, J., \& McLean, D. (2020). The impact of Covid-19 on initial teacher training. NFER. https:// www.nfer.ac.uk/media/4143/the_impact_of_covid_19_on_initial_teacher_training.pdf Wyse, A. E., Stickney, E. M., Butz, D., Beckler, A., \& Close, C. N. (2020). The potential impact of COVID-19 on student learning and how schools can reopen. Educational Measurement: Issues and Practice, 39(3), 60-64. https://doi.org/10.1111/emip.12357

Yorke, L., Rose, P. Hagos, B., \& Woldehanna, T. (2020). The effects of COVID-19 on primary education in Ethiopia: Perspectives of school principals and teachers (Report No. 20/10). REAL Centre, University of Cambridge. https://www.educ.cam.ac.uk/centres/real/publications/Effects\%20of\%20 COVID-19\%20on\%2oprincipals\%2oand\%2oteachers_Ethiopia.pdf Young Lives (n.d., a). Young lives school survey: Child questionnaire 1 [primary] https://www. younglives.org.uk/sites/www.younglives.org.uk/files/Vietnam-School-Survey_R1-W1_Childquestionnaire.pdf Young Lives (n.d., b). Young lives school survey: Secondary school survey. https://www.younglives.org. uk/sites/www.younglives.org.uk/files/VN\%20W2\%20-\%20Student\%20Questionnaire\%2o(EN).pdf

\section{Biographical note}

Riıkka Hofmann, PhD, is an Associate Professor at the Faculty of Education, University of Cambridge and fellow at Hughes Hall, Cambridge. She leads the Research Strand 'Dialogue, Professional Change and Leadership' in the Cambridge Educational Dialogue Research Group CEDiR; her research develops conceptual models of complex professional learning outcomes and their generative mechanisms, particularly investigating scalable professional change interventions in education. As expert advisor, she actively facilitates policy and practice-based research across UK-Government.

Gabrielle Arenge is a doctoral researcher in teacher professional learning and development at the Faculty of Education, University of Cambridge. Her doctoral research investigates the professional learning processes that catalyse pedagogic change in Southern African schools.

Siobhan Dickens is a doctoral researcher in professional learning at the Faculty of Education, University of Cambridge, UK. Her doctoral research investigates subject-specialist professional learning of secondary History teachers using sociocultural approaches including dialogic methods. 
JAVIERA MARFán is a doctoral researcher in educational policy at the Faculty of Education, University of Cambridge. She investigates processes of school change motivated by the enactment of a multi-goal, high-stakes accountability reform in Chile, using embedded multi-case studies.

MAIREAd Ryan is an interdisciplinary $\mathrm{PhD}$ student at the MRC Epidemiology Unit and Faculty of Education, University of Cambridge. Her PhD aims to identify features of effective school-based physical activity interventions.

Ngee Derk, Tiong is a doctoral researcher in teacher professional learning and development at the Faculty of Education, University of Cambridge. His doctoral research investigates teachers' discourse practices and the learning opportunities afforded by professional conversations.

BhaveEt RAdia is a part-time doctoral researcher at the Faculty of Education, University of Cambridge. His doctoral research investigates the development of clinical leadership. He is Head of the Learning Lab at Guy's and St Thomas' NHS Foundation Trust.

Lenka Janik BLAskova is a doctoral researcher in psychology and education at the University of Cambridge. She investigates peer relationships and wellbeing of children with developmental language disorder. Lenka promotes participatory research with children when exploring their social lives. 